\title{
Forms of soluble iron in mouse stomach and duodenal lumen: significance for mucosal uptake
}

\author{
BY ROBERT J.SIMPSON* AND T. J. PETERS* \\ Division of Clinical Cell Biology, Clinical Research Centre, Watford Road, Harrow, \\ Middlesex HAl $3 \mathrm{UJ}$
}

(Received 4 May 1989 - Accepted 29 August 1989)

\begin{abstract}
Stomach contents of mice fed on a standard rodent breeding diet contained $29-733 \mu \mathrm{M}-$-soluble nonhaem-iron. A very variable percentage (3-100, mean $49 \cdot 3$ (SE 4.7), $n$ 37) of this Fe was rapidly (half-life $<1-2$ s) available for chelation by the strong $\mathrm{Fe}$ (II) chelator ferrozine, with little or no further $\mathrm{Fe}$ being available on addition of ascorbate. Ferrozine-available Fe could be detected in the duodenal lumen at concentrations up to $60 \mu \mathrm{M}$ in vivo and after in vitro neutralization of stomach contents. No significant changes in quantity of stomach ferrozine-available Fe or soluble non-haem-Fe occurred in mice with adaptive enhancement of $\mathrm{Fe}$ absorption induced by chronic hypoxia. Electron paramagnetic resonance (e.p.r.) spectroscopy of the soluble portion of mouse stomach contents demonstrated a $g=4 \cdot 3$ signal (rhombic $\mathrm{Fe}(\mathrm{III})$ ) equivalent to up to $20 \%$ of soluble non-haem-Fe. The signal was unaffected by addition of excess ferrozine and increased on subsequent neutralization, suggesting redistribution of Fe from other e.p.r.-silent species. Solutions of Fe-nitrilotriacetate (NTA) (a synthetic Fe chelate used as a bioavailable, model Fe solution) were found to contain both rapidly and slowly ferrozine-available $\mathrm{Fe}$ (after addition of ascorbate) depending on $\mathrm{pH}$, NTA:Fe ratio and the presence of $\mathrm{Ca}$ (II) ions. $\mathrm{Fe}$-ascorbate mixtures (a model solution for Fe absorption studies) also contained ferrozine-available Fe. These results suggest the presence of Fe(II), rhombic Fe(III) and other e.p.r.-silent Fe species in the soluble fraction of mouse stomach contents. The ferrozine-available (Fe(II)) fraction is not limited by the reducing power in the diet, but by binding to ligands. Neutralization with bicarbonate leads to a loss of ferrozine-available $\mathrm{Fe}$ and increase in rhombic $\mathrm{Fe}$ (III) at the expense of both ferrozine-available and other e.p.r.-silent Fe species. The ferrozine-available $\mathrm{Fe}$ in mouse stomach and duodenal lumen can be related to Fe species present in model solutions used for in vitro studies of mucosal uptake mechanisms.
\end{abstract}

Duodenal iron uptake: Iron availability: Mouse

Recent studies of mucosal uptake of iron by mouse duodenum have suggested the existence of two separate cellular mechanisms of uptake (Raja et al. 1987 b; Peters et al. 1988). One mechanism appears to represent uptake from unstable, unchelated $\mathrm{Fe}$ (II) or $\mathrm{Fe}$ (III) species present in fresh $\mathrm{Fe}$-ascorbate solutions (a model bioavailable $\mathrm{Fe}$ solution) or $\mathrm{Fe}$ nitrilotriacetate (NTA) solutions destabilized by, for example, addition of Ca(II) ions (Raja et al. 1987 b; Simpson \& Peters, 1987; Simpson et al. 1988). This mechanism is thought to be mediated by non-esterified fatty acids (Simpson \& Peters, 1987; Simpson et al. 1988). Investigation of $\mathrm{Fe}$-ascorbate solutions with the chelators ferrozine and mimosine and by physical techniques (Dorey et al. 1987) showed instability above $\mathrm{pH} 7.0$ due to probable formation of small polymeric Fe(III) species, these not being available for transport by nonesterified fatty acids (Simpson \& Peters, 1987). The second uptake mechanism relates to uptake of Fe from weakly chelated Fe(III) (e.g. Fe-NTA $(1: 2)$ but not Fe-EDTA $(1: 2)$ ).

The question arises as to what forms of $\mathrm{Fe}$ are available in the duodenal lumen during physiological processes and which solutions represent good models for these forms of $\mathrm{Fe}$.

\footnotetext{
* Present address: Department of Clinical Biochemistry, King's College School of Medicine and Dentistry, Denmark Hill, London SE5 9PJ.
} 
No direct information is available to answer this question. In mice, the duodenal lumen volume is too small for many forms of analysis. In addition, uptake of available Fe forms may be of high efficiency, hence the available forms would not be easy to detect. The unstable Fe species described above may have a lifetime of only a few minutes and no specific information is available regarding the effect of dietary ligands on these species.

It is also clear that some investigation of the forms of Fe present in mouse duodenal lumen during digestion of diet is required. Due to the rapidity of transit of dietary material through the duodenum (average residence time approximately $1 \mathrm{~min}$; Raja et al. 1987 a) two approaches are adopted in the present paper, namely: (1) investigation of the stomach contents with attempts to model changes occurring in the duodenum and (2) direct study of mouse duodenal contents. Model solutions, as used in previous in vitro Fe absorption studies, are also investigated.

\section{MATERIALS AND METHODS}

\section{Animals and diets}

Male, To strain, 6-8-week-old (25-30 g) mice were used throughout and fed on a commercial pelleted rodent diet (Labsure diet ERD; Manea, Cambs) ad lib. except on the day of an experiment. This diet contained $3 \cdot 1$ (SE 0.3) nmol non-haem-Fe/g ( $n 3$ ). Insignificant amounts $(<0.01 \mathrm{nmol} / \mathrm{g})$ of haem-Fe were present. The diet was made from maize, wheat, white-fish meal, soya-bean meal, wheat germ and dried Brewer's yeast, with a mineral and vitamin supplement including $50 \mathrm{mg}$ ferrous sulphate $/ \mathrm{kg}$. The diet contained (g/kg): 207 protein, 33 oil, 24 fibre, the remainder being minerals, carbohydrate and ash (details as supplied by the manufacturer).

Hypoxia was induced by placing mice in a hypobaric chamber at a pressure of $50.7 \mathrm{kPa}$ $(0.5 \mathrm{~atm})$ for $3 \mathrm{~d}$. Food and water were given ad lib. Experiments with hypoxic mice were performed within $30 \mathrm{~min}$ of removal from the chamber, no diet being given during this period. Mice were starved overnight in wire-bottomed cages.

\section{Investigation of $\mathrm{Fe}$ in stomach and duodenal contents}

Mice were killed by anaesthetizing with methoxyfluorane (Metaphane; C-Vet, Bury St Edmunds, Suffolk) followed by cervical dislocation. Mouse stomachs were removed and opened on a plastic sheet. The lumen $\mathrm{pH}$ was determined using a Pye Unicam/Ingold MS E7 micro flat-headed pH electrode with a WPA Scientific Instruments (SEMAT (UK), London) $\mathrm{CD} 60 \mathrm{pH}$ meter calibrated to $0 \cdot 1$ unit over the $\mathrm{pH}$ range $1 \cdot 0-7 \cdot 0$. The stomach contents were transferred to a weighed tube and centrifuged at $10000 \mathrm{~g}$ for $2 \mathrm{~min}$. The supernatant fraction was removed, weighed and a portion $(10-20 \mu \mathrm{l})$ added to a cuvette containing $1 \mathrm{ml} 0.8 \mathrm{~mm}$-ferrozine. The increase in absorbance at $562 \mathrm{~nm}$ was recorded until it stabilized, then $20 \mu 10 \cdot 1 \mathrm{M}$-sodium ascorbate were added and further change in absorbance was recorded.

\section{Analytical procedures}

Non-haem-Fe was determined using the method of Foy et al. (1967) except that ferrozine (Sigma Chemical Co., Poole, Dorset) was used as an Fe indicator. Analar reagents were used throughout (BDH Chemicals, Poole, Dorset) with appropriate blanks to correct for reagent $\mathrm{Fe}$ contamination. Electron paramagnetic resonance (e.p.r.) spectra of frozen (liquid nitrogen, stored at $-70^{\circ}$ ), pooled supernatant fractions of stomach contents from up to four mice were recorded with a Varian $x$-band $(9300 \mathrm{MHz})$ spectrometer. Samples were gas cooled to about $-173^{\circ}$ in the Varian low-temperature accessory. Spectrometer settings were: microwave power $200 \mathrm{~mW}$, modulation amplitude $10 \mathrm{G}$, modulation 
frequency $100 \mathrm{kHz}$, time constant $0.3 \mathrm{~s}$, sweep rate $500 \mathrm{G} / \mathrm{min}$. Peak intensities were estimated as equivalent $\mathrm{Fe}$ concentrations by comparison with Fe(III)-NTA (1:2) solutions in the same tube, after background signal subtraction.

Ferrozine-available $\mathrm{Fe}$ in duodenal contents was determined by removing the proximal $35 \mathrm{~mm}$ of small intestine from mice killed as described previously, and washing out the

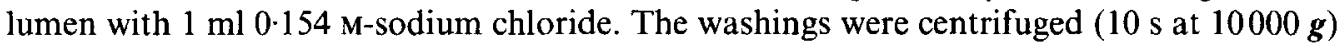
to remove insoluble material, then placed in a semi-microcuvette and the absorbance at $562 \mathrm{~nm}$ recorded before and after addition of $20 \mu \mathrm{l} 10 \mathrm{~mm}$-ferrozine and $20 \mu 10 \cdot 1 \mathrm{M}$-sodium ascorbate.

\section{Availability of $\mathrm{Fe}$ in model solutions}

Ferric chloride, Fe-NTA $(1: 2)$ and Fe-EDTA $(1: 2)$ in water were prepared by mixing $10 \mathrm{mM}^{-\mathrm{FeCl}_{3}}$ in $10 \mathrm{~mm}$-hydrochloric acid, $10 \mathrm{~mm}-\mathrm{NTA}(\mathrm{Na})_{3}$ or $10 \mathrm{~mm}-\mathrm{EDTA}(\mathrm{Na})_{3} \mathrm{H}$ $\left(\mathrm{pH} \mathrm{7.4)}\right.$ where appropriate and diluting with water to give 20-200 $\mu \mathrm{M}-\mathrm{Fe} . \mathrm{FeSO}_{4}$ was diluted from a $10 \mathrm{~mm}$ solution in $10 \mathrm{~mm}-\mathrm{HCl}$. The $\mathrm{pH}$ of these solutions was $3 \cdot 3-4 \cdot 8$. The solutions and mixtures obtained by neutralization to $\mathrm{pH} 6 \cdot 5-7 \cdot 0$ with small volumes of $0.5 \mathrm{M}$-sodium bicarbonate were investigated for availability of $\mathrm{Fe}$ to chelators by adding water, $2 \mathrm{~mm}$ (final)-sodium ascorbate and $200 \mu \mathrm{M}$-ferrozine (final); each as $0.02 \mathrm{vol}$. of a fifty-fold concentrated solution to give a final Fe concentration of less than $50 \mu \mathrm{M}$, then observing ferrozine- $\mathrm{Fe}(\mathrm{II})$ formation.

Fe-NTA (1:2) incubation media in $20 \mathrm{~mm}$-Hepes (pH 7.4), $0 \cdot 1 \mathrm{M}-\mathrm{NaCl}, 0 \cdot 1 \mathrm{M}-$ mannitol, was prepared by mixing $\mathrm{FeCl}_{3}$ and $\mathrm{NTA}(\mathrm{Na})_{3}$ solutions as described previously with a twofold concentrated Hepes-mannitol- $\mathrm{NaCl}$ solution and incubating for $5 \mathrm{~min}$ at $37^{\circ}$. Ferrozine and sodium ascorbate were added as described previously and absorbance at $562 \mathrm{~nm}$ recorded.

\section{Statistical analysis}

Values were tested for normality (Royston, 1983) and quoted as means with their standard errors, or median with interquartile limits, as appropriate. Groups of values were compared by Wilcoxon's Rank Sum test (Wetherill, 1967). Correlations were determined by linear regression.

\section{RESULTS}

\section{Stomach contents}

The stomach contents from mice, separated into soluble and insoluble material, are shown in Fig. 1. The normal feeding pattern for the mice used in the present study was to feed at $11.00-12.00 \mathrm{~h}$ and this is reflected by the increase in solids in the stomach noted at this time. Normal daily diet consumption was 4.24 (SE 0.37$) \mathrm{g}(n 20)$ with no correlation between bodyweight and daily consumption $(r 0.07, n 20, P=0.78)$. Experiments in which $12 \mathrm{~h}$-fasted mice were allowed to refeed, demonstrated a maximum stomach content of approximately $250 \mathrm{mg}$ diet, suggesting a mean residence time of less than $2 \mathrm{~h}$ for diet in the stomach. In spite of this, Fig. 1 shows that short-term $(4.5 \mathrm{~h})$ withholding of diet does not significantly deplete the stomach, presumably due to reduced emptying on fasting. Even fasting for $16 \mathrm{~h}$ leaves mice with some material in the stomach (Fig. 1).

The quantity of diet solids in stomachs of hypoxic mice was not significantly different from that in normal mice fasted for up to $4.5 \mathrm{~h}$. The percentage of total stomach contents which was soluble was variable (range $26 \cdot 0-60 \cdot 3$, median $31 \cdot 3$, interquartile limits $27 \cdot 8-38 \cdot 9$, $n 11)$ and was not significantly affected by $4 \mathrm{~h}$ of fasting.

\section{Stomach $\mathrm{pH}$}

Stomach $\mathrm{pH}$ may be a major influence on the availability of Fe for absorption (Hungerford $\&$ Linder, 1983). Stomach $\mathrm{pH}$ values for various groups of fed, fasted and hypoxic mice are 
(a) Soluble

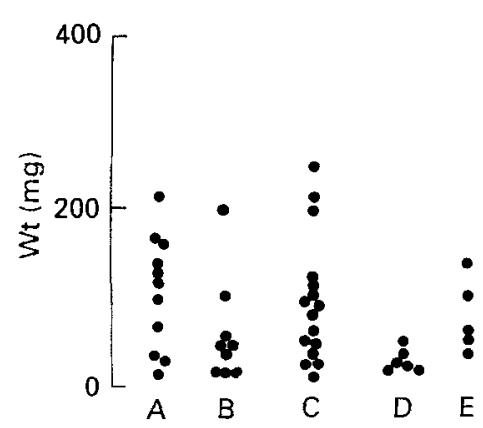

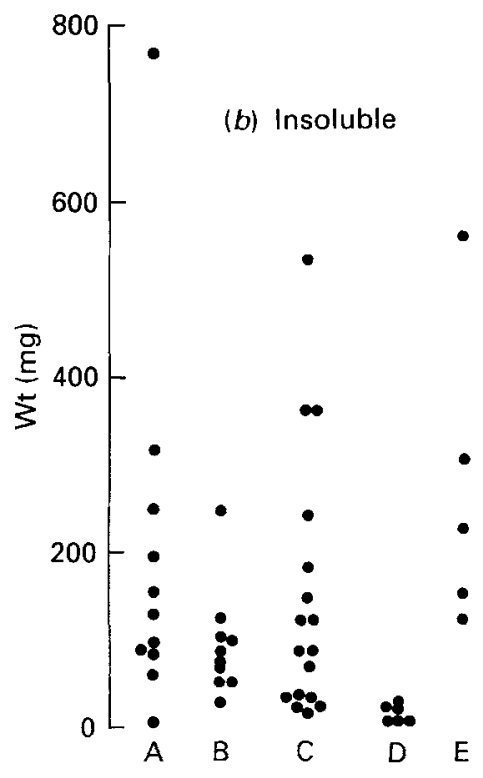

Fig. 1. Stomach contents of mice. Quantity of $(a)$ soluble and $(b)$ insoluble material in mouse stomach. Mice were (A) ad lib. fed till 09.00 hours, analysed between 09.00 and 10.30 hours; (B) fasted from 09.00 hours, analysed between 13.30 and 14.30 hours; (C) ad lib. fed in a hypobaric chamber at a pressure of $50.7 \mathrm{kPa}$ for $3 \mathrm{~d}$, analysed between 09.00 and 10.30 hours; (D) fasted for $16 \mathrm{~h}$ before analysis at 09.00 hours; (E) ad lib. fed and analysed at $11.30-13.00$ hours.

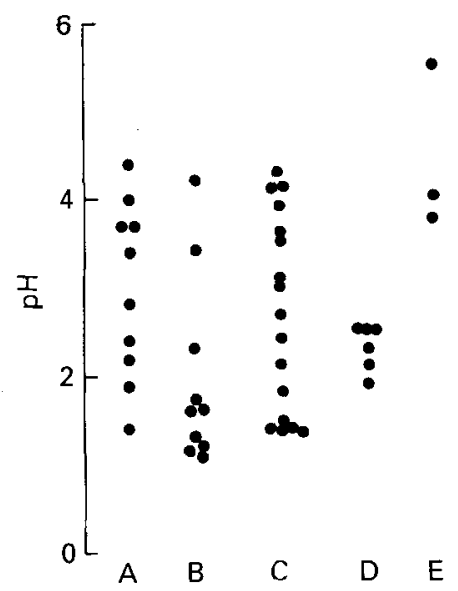

Fig. 2. pH of mouse stomach contents. Mice were (A) ad lib. fed till 09.00 hours, analysed between 09.00 and 10.30 hours; (B) fasted from 09.00 hours, analysed between 13.30 and 14.30 hours; (C) ad lib. fed in a hypobaric chamber at a pressure of $50.7 \mathrm{kPa}$ for $3 \mathrm{~d}$, analysed between 09.00 and 10.30 hours; (D) fasted for $16 \mathrm{~h}$ before analysis at 09.00 hours; (E) ad lib. fed and analysed at 11.30-13.00 hours.

shown in Fig. 2. A wide range of $\mathrm{pH}$ values was observed with no significant difference between $0-1.5 \mathrm{~h}$ fasted, $3.5-4.5 \mathrm{~h}$ fasted and hypoxic mice. There was a positive correlation between stomach $\mathrm{pH}$ and the quantity of solids found in the stomach (Figs. 1 and 2). This correlation was also evident when all normal and hypoxic stomach $\mathrm{pH}$ and solid content values were compared by linear regression $(r 0.673, n 23, P<0.001)$. This may be presumed to reflect the tendency of food to neutralize the stomach acid. The observation that $3 \cdot 5-4.5 \mathrm{~h}$ 


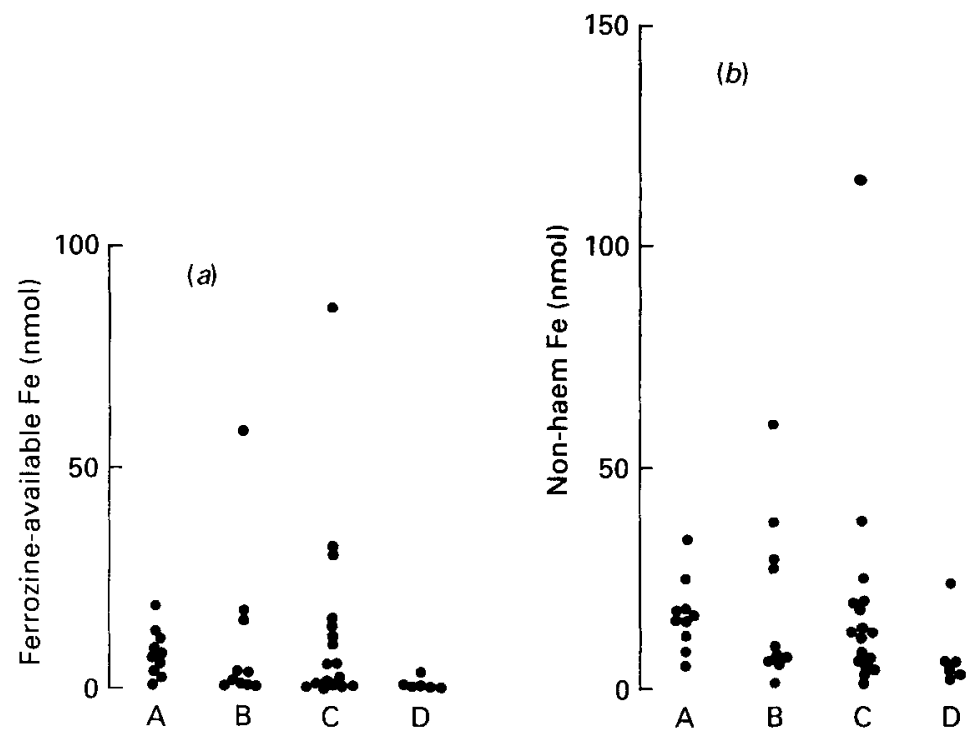

Fig. 3. (a) Rapidly ferrozine-available and (b) non-haem-iron levels (nmol) in soluble fraction of mouse stomach contents. Ferrozine-available Fe is Fe reacting within $5 \mathrm{~s}$ with $0.8 \mathrm{~mm}$-ferrozine solution. Mice were (A) ad lib. fed till 09.00 hours, analysed between 09.00 and 10.30 hours; (B) fasted from 09.00 hours, analysed between 13.30 and 14.30 hours; (C) ad lib. fed in a hypobaric chamber at a pressure of $50.7 \mathrm{kPa}$ for $3 \mathrm{~d}$, analysed between 09.00 and 10.30 hours; (D) fasted for $16 \mathrm{~h}$ before analysis at 09.00 hours.

fasting does not greatly reduce solid content or $\mathrm{pH}$ suggests that the correlation is not a consequence of the time elapsed since feeding.

Small intestinal $\mathrm{pH}$, measured at the mucosal surface, was found to be much more constant, namely: duodenum pH 6.46 (SE 0.03), $n$ 16; jejunum pH 6.57 (SE 0.08), $n$ 16; ileum $\mathrm{pH} 7 \cdot 11$ (SE 0.09), $n$ 6. These values resemble those reported for the rat (Hungerford \& Linder, 1983).

\section{Stomach Fe}

Total stomach Fe was found to vary greatly from one animal to another but no significant difference between the groups of mice was observed (Fig. 3). The majority of Fe was insoluble (median $8.9 \%$ soluble, interquartile limits $5.4-18.1 \%, n 37$ ). The quantity of insoluble $\mathrm{Fe}$, relative to the total solids in the stomach, was found to show a positive correlation $(r 0.408, P<0.01, n 37)$ with the stomach $\mathrm{pH}$, as would be expected if lower $\mathrm{pH}$ values show a tendency to solubilize Fe. Soluble total Fe was significantly lower in $16 \mathrm{~h}$ starved mice compared with fed animals. There was no significant difference between soluble $\mathrm{Fe}$ in hypoxic and $4.5 \mathrm{~h}$ starved mice.

Fe rapidly available to the $\mathrm{Fe}$ (II) chelator ferrozine was observed in most stomachs (Fig. 3 ). In only four of thirty-seven stomachs was negligible ferrozine-available Fe present. In four of thirty-seven stomachs there was significant additional $\mathrm{Fe}$ available on addition of ascorbate ( $2 \mathrm{mM})$. Ferrozine-available Fe represented a variable percentage of soluble nonhaem-Fe (3-100, mean 49-3 (SE 4-7), $n$ 37). No significant differences in ferrozine-available $\mathrm{Fe}$ or soluble non-haem-Fe were detectable between the three groups $0-1 \cdot 5 \mathrm{~h}$ fasted, $3 \cdot 5-$ $4.5 \mathrm{~h}$ fasted and hypoxic.

\section{Duodenal ferrozine-available $\mathrm{Fe}$}

Ferrozine-availability of $\mathrm{Fe}$ in mouse duodenum was investigated both by direct analysis of duodenal contents and by in vitro neutralization of stomach contents (Table 1). In seven 
Table 1. Rapidly ferrozine-available iron in mouse duodenal contents and neutralized stomach contents

\begin{tabular}{|c|c|c|c|}
\hline $\begin{array}{c}\text { Mouse } \\
\text { no. }\end{array}$ & $\begin{array}{c}\text { Stomach } \\
\text { rapidly } \\
\text { ferrozine- } \\
\text { available } \\
\mathrm{Fe}(\mathrm{nmol} / \mathrm{mg})\end{array}$ & $\begin{array}{c}\text { Rapidly } \\
\text { ferrozine- } \\
\text { available Fe } \\
\text { in neutralized } \\
\text { stomach } \\
\text { contents } \\
(\mathrm{nmol} / \mathrm{mg})\end{array}$ & $\begin{array}{c}\text { Duodenal } \\
\text { rapidly } \\
\text { ferrozine- } \\
\text { available } \\
\mathrm{Fe}(\mathrm{nmol} / \mathrm{mg})\end{array}$ \\
\hline 1 & 47 & 0 & 0 \\
\hline 2 & 27 & 0 & 0.3 \\
\hline 3 & 27 & 17 & 0.3 \\
\hline 4 & 35 & 16 & 0.6 \\
\hline 5 & 9 & 0 & 0.3 \\
\hline 6 & 38 & 17 & 0.3 \\
\hline 7 & 49 & 23 & 0.3 \\
\hline 8 & 15 & ND & 0 \\
\hline 9 & 11 & ND & 0 \\
\hline 10 & 4 & ND & 0.1 \\
\hline 11 & 113 & ND & 0.23 \\
\hline 12 & 161 & ND & 0.04 \\
\hline 13 & ND & ND & 0.27 \\
\hline 14 & ND & ND & 0 \\
\hline 15 & 250 & 40 & ND \\
\hline 16 & 38 & 0 & ND \\
\hline 17 & 20 & 0 & ND \\
\hline
\end{tabular}

ND, not determined.

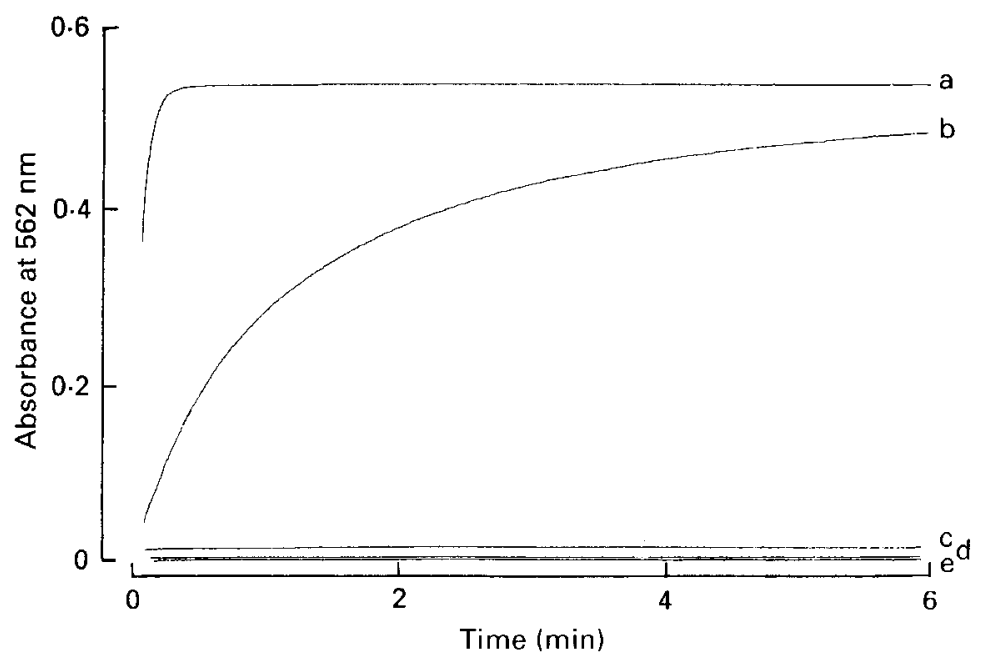

Fig. 4. Reaction of different iron complexes with ferrozine/ascorbate mixture. Fe-ligand solutions were mixed with $200 \mu \mathrm{M}$-ferrozine, $2 \mathrm{mM}$-sodium ascorbate at zero time and absorbance at $562 \mathrm{~nm}$ recorded. Temperature was $21^{\circ}$ and Fe concentration $20 \mu \mathrm{M}$. (a) Fe-nitrilotriacetate (NTA) (1:2), pH 4.2; (b) Fe-NTA (1:2), pH 7.3; (c) Fe EDTA (1 :2), pH 4-9; (d) Fe-EDTA (1 :2), pH 7.4; (e) no Fe blank. Low-pH mixtures were obtained by mixing equal volumes of ferric chloride in hydrochloric acid with trisodium salts of EDTA or NTA. Neutralized samples were obtained from acid solutions by adding small volumes of $0.5 \mathrm{M}$-sodium bicarbonate. 
mice, both approaches were adopted, six of them demonstrating detectable ferrozineavailable $\mathrm{Fe}$ in the duodenum and four in the neutralized stomach contents. Three of these latter four showed further, slowly-available Fe. In all, ten of fourteen mice showed detectable ferrozine-available $\mathrm{Fe}$ in duodenal contents and five of ten showed such $\mathrm{Fe}$ in in vitro neutralized stomach contents. The quantities of duodenal lumen available Fe were close to the detection limits, but nevertheless the consistency of the findings shows that it is a real observation. Further support for the presence of rapidly ferrozine-available $\mathrm{Fe}$ in the duodenum comes from the neutralization experiments, although there was invariably some loss of stomach ferrozine-available Fe on neutralization.

\section{Other Fe species in the stomach soluble fraction}

Pooled stomach contents from several mice were used to search for other Fe species by e.p.r. Small $g=4.3$ signals (tetrahedral symmetry $\mathrm{Fe}(\mathrm{III})$ ) were observed in all three samples studied, the signal intensity corresponding to $10-20 \%$ on non-haem-Fe present. This signal increased in intensity on in vitro neutralization of stomach contents to approximately $50 \%$ of non-haem-Fe present. Addition of ferrozine had no effect on the signal intensity although Fe-ferrozine complex formation was visible. These observations suggest that the soluble, non-ferrozine-available Fe consists of at least two species, one observable as $g=4 \cdot 3$ $\mathrm{Fe}(\mathrm{III})$ and one e.p.r.-silent. Ferrozine-available Fe is also e.p.r.-silent and may, therefore, be assumed to be $\mathrm{Fe}$ (II) at the low $\mathrm{pH}$ of the stomach. The $g=4 \cdot 3 \mathrm{Fe}$ (III) species increases at the expense of the other species on in vitro neutralization of stomach contents.

\section{Analysis of model solutions}

Model solutions Fe-NTA $(1: 2)$ (weakly chelated), Fe-EDTA $(1: 2)$ (strongly chelated), $\mathrm{FeCl}_{3}, \mathrm{FeSO}_{4}$ and $\mathrm{Fe}$-ascorbate were investigated for availability of the $\mathrm{Fe}$ for rapid chelation by ascorbate/ferrozine. Fe-NTA $(1: 2)$ was rapidly available at $\mathrm{pH} 4 \cdot 2$ (stomach equivalent), but only slowly available (half-life $1 \mathrm{~min}$ ) at $\mathrm{pH} 7 \cdot 3$ (Fig. 4). Fe-EDTA (1:2) was essentially unavailable at both $\mathrm{pH} 4 \cdot 2$ and $7 \cdot 3$ (Fig. 4). Fe-ascorbate has been studied previously (Dorey et al. 1987). Briefly the results show that the $\mathrm{Fe}$ is completely rapidly available up to $\mathrm{pH} 6 \cdot 8$. At higher $\mathrm{pH}$ the $\mathrm{Fe}$ is converted to slowly available forms.

$\mathrm{FeCl}_{3}$ and $\mathrm{FeSO}_{4}$ were found to be completely rapidly available at $\mathrm{pH} 3 \cdot 3-4 \cdot 0$. Rapidly available $\mathrm{Fe}$ disappeared almost instantly from $\mathrm{FeCl}_{3}$ on neutralization with bicarbonate, but slowly available Fe persisted for at least $25 \mathrm{~min}$ at $37^{\circ}$. The rate of availability of the slowly available $\mathrm{Fe}$ species declined over several minutes, the decline being slower at $\mathrm{pH}$ 6.5 than at $\mathrm{pH} \mathrm{7.3} . \mathrm{FeSO}_{4}$ demonstrated rapidly available $\mathrm{Fe}$ for only slightly longer than $\mathrm{FeCl}_{3}$ after neutralization, with $15 \%$ of $\mathrm{Fe}$ still rapidly available after $70 \mathrm{~s}$ at $37^{\circ}$, irrespective of whether ascorbate was added with the ferrozine. This demonstrates that Fe(II) persists, albeit briefly, on neutralization of Fe(II) solutions in the presence of air. Slowly available Fe persisted in a much less time-dependent form than is observed with neutralized $\mathrm{FeCl}_{3}$, suggesting formation of different species than those formed from $\mathrm{FeCl}_{3}$ and $\mathrm{NaHCO}_{3}$. When $\mathrm{FeSO}_{4}$ was neutralized with a $\mathrm{NaHCO}_{3}$-sodium ascorbate mixture $(0.5 \mathrm{M}$ and $1 \mathrm{~mm}$ respectively) to $\mathrm{pH} 6.5$, relatively stable, rapidly chelatable forms of $\mathrm{Fe}$ were present.

Investigation of the availability of $\mathrm{Fe}$ in $\mathrm{Fe}-\mathrm{NTA}-\mathrm{Hepes}-\mathrm{NaCl}-$ mannitol mixtures, as used in studies of brush-border-membrane vesicle and non-esterified fatty acid-mediated $\mathrm{Fe}$ transport (Simpson \& Peters, 1984; Simpson et al. 1988), showed that the availability of $\mathrm{Fe}$ for chelation, as measured by initial rates of ferrozine-Fe(II) formation after addition of ascorbate plus ferrozine, exactly parallels non-esterified fatty acid-mediated Fe uptake by vesicles (Fig. 5). In particular, the effects of varying the NTA: Fe ratio, Fe-NTA (1:2) 


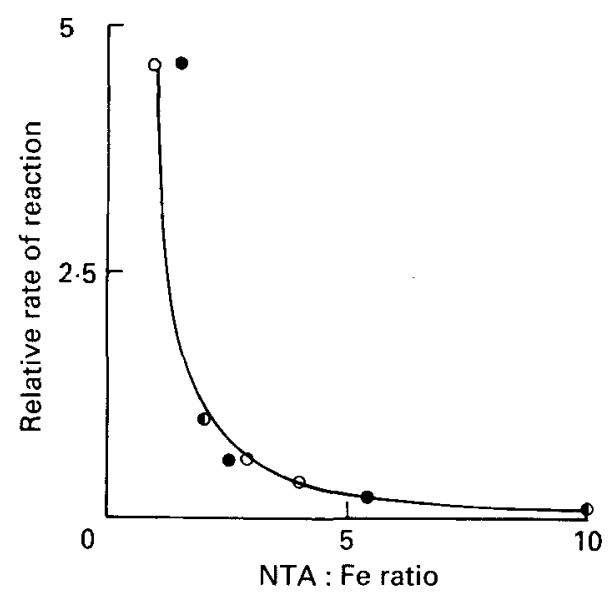

Fig. 5. Effect of nitrilotriacetate (NTA):iron ratio on rate of reaction with ferrozine/ascorbate mixture. Fe-NTA mixtures were prepared and incubated for $5 \mathrm{~min}$ at $21^{\circ}(90 \mu \mathrm{M}-\mathrm{Fe}$ (III), $0.1 \mathrm{M}$-sodium chloride, $0.1 \mathrm{M}$-mannitol, 20 mm-Hepes, pH 7.4, various NTA concentrations (for details, see Simpson \& Peters, 1984), then $200 \mu \mathrm{M}$ (final)ferrozine and $2 \mathrm{~mm}$-sodium ascorbate added at zero time and absorbance at $562 \mathrm{~nm}$ recorded. Relative initial rates of reaction were determined and are plotted against NTA : Fe ratio (O). Also shown is the effect of a similar variation in NTA: Fe ratio on brush-border-membrane vesicle ${ }^{59} \mathrm{Fe}$ (III) uptake from similar solutions (O) (from Simpson \& Peters, 1984).

concentration, and adding $\mathrm{Ca}$ (II) (not shown) all showed a correlation between availability of Fe for chelation by ferrozine/ascorbate and availability of Fe for non-esterified fatty acid-mediated transport. This correlation was further emphasized by the higher availability and transport seen with fresh Fe-ascorbate solutions compared with $\mathrm{Fe}-\mathrm{NTA}$ solutions (Simpson et al. 1988).

\section{DISCUSSION}

The findings provide information about the concentrations and chemical forms of $\mathrm{Fe}$ present in mouse stomach and duodenal lumen during digestion of a commercial rodent diet capable of supporting normal mouse growth. It is clear that in mice, fasting for at least $16 \mathrm{~h}$ is necessary to largely clear the stomach of endogenous Fe. Our previous studies of mechanisms of mucosal $\mathrm{Fe}$ uptake have generally employed fed mice and one proposed mechanism of uptake, namely non-esterified fatty acid-mediated brush-border-membrane Fe transport (Simpson et al. 1988), may be sensitive to fasting (Simpson et al. 1986); others have also shown that fasting or semi-starvation can affect $\mathrm{Fe}$ absorption (Hopping \& Ruliffson, 1963; Conrad et al. 1967; Forth \& Schafer, 1987). However, the effects of fasting on the dietary constituents were not easy to exclude in such studies.

Many workers have injected or infused acid (i.e. $\mathrm{pH}$ 2) solutions into duodenal or jejunal lumen as a model for orally administered Fe leaving the stomach. Our studies show that in mice, the stomach $\mathrm{pH}$ is relatively high when large amounts of diet are present and thus, during normal dietary absorption after feeding, a higher $\mathrm{pH}$ (3-5) is more appropriate. Similar effects of food on stomach pH have been shown in man (James \& Pickering, 1949).

Over the past 30 years many studies of $\mathrm{Fe}$ absorption have been performed and a wide range of Fe concentrations have been selected for these studies, e.g. Stremmel et al. (1987) used concentrations below $1 \mu \mathrm{M}$; Muir et al. (1984), Eastham et al. (1977) and Marx \& Aisen (1981) favoured 1-20 $\mu \mathrm{M}$; Cox \& O'Donnell (1981), Simpson \& Peters (1984, 1985), Cox \& Peters (1979), Forth \& Rummel (1973), Manis \& Schachter (1964), Ruliffson \& 
Hopping (1963), Huebers et al. (1974), Johnson et al. (1983), Hungerford \& Linder (1983), Becker et al. (1979) and Berner et al. (1986) have favoured 20-500 $\mu \mathrm{M}$; while still higher or more widely variable concentrations have been chosen by many (Greenberger et al. 1967; Helbock \& Saltman, 1967; Pearson et al. 1967; Thomson \& Valberg, 1971; Terato et al. 1973; Savin \& Cook, 1980; Barton et al. 1983). The reasoning behind the choice of Fe concentrations may also be variable.

Thus, most rodent diets contain total non-haem-Fe levels equivalent to stomach concentrations in the range $1-10 \mathrm{mM}$, but the presence of saturable uptake in the range $50-500 \mu \mathrm{M}$ has suggested this as the physiological range of concentrations available for absorption. In vitro studies have favoured lower Fe concentrations because of the danger of tissue damage by the Fe. Ignorance of the molecular mechanism of Fe uptake, has limited chemical investigation of possible available $\mathrm{Fe}$ in the intestinal lumen, to a variety of in vitro studies of $\mathrm{Fe}$ release to $\mathrm{Fe}(\mathrm{II})$ chelators or studies of $\mathrm{Fe}$ dialysability, and to studies of $\mathrm{Fe}$ solubility or dialysability after mixture with gastric juice or in jejunal aspirates.

Extensive studies of the reaction of Fe salts with human gastric juice (Davis et al. 1967; Wynter \& Williams, 1968; Webb et al. 1973) have not provided information on the availability of the chemical forms studied, simply that a major mucoprotein component of gastric juice can combine with and solubilize Fe after neutralization. Analysis of dietary Fe in jejunal aspirates from humans has been attempted (Glover \& Jacobs, 1971), but only crude molecular weight estimates of Fe species present were made. These techniques provide no information about transient or unstable species likely to be present during the rapid transit and neutralization of stomach contents in the duodenal lumen, nor do they provide information on the availability of the observed Fe species for uptake by the duodenal mucosa.

Release of Fe to chelators in vitro has been studied after varying periods of incubation with $\alpha, \alpha$-bipyridyl or tripyridyltriazine after addition of reducing agents and sometimes strong acid (Kohler et al. 1936; Shackleton \& McCance, 1936; Sanford, 1960; Jacobs \& Greenman, 1969; Narasinga Rao \& Prabhavathi, 1978; Lock \& Bender, 1980). The term ionizable Fe has frequently been used to describe the chelatable Fe. These early studies do not, however, provide information on the presence of Fe suitable for absorption by nonesterified fatty acid-mediated mechanisms in the duodenum. Ferrozine was recently used by Reddy et al. (1986) to assess Fe forms present in in vitro digests of one particular diet, namely pinto beans (Phaseolus vulgaris). They found that the diet did not have sufficient reducing power to produce physiologically significant $\mathrm{Fe}(\mathrm{II})$ concentrations, unlike the rodent diet employed by us, which clearly does contain significant $\mathrm{Fe}(\mathrm{II})$, at least in the low $\mathrm{pH}$ of the stomach.

The findings further show that rapidly chelatable Fe persists in the duodenum, the main site of Fe absorption (Wheby \& Crosby, 1963) and that in vitro neutralized stomach contents can also contain, at least transiently, such Fe. This rapidly chelatable Fe is also available for absorption by non-esterified fatty acid-mediated brush-border-membrane $\mathrm{Fe}$ transport (Simpson \& Peters, 1987), suggesting that this proposed mechanism of Fe uptake can play a part in normal uptake of dietary Fe by mice. Our findings also suggest that the physiological concentration of Fe available for absorption in mouse duodenum is in the range $10-100 \mu \mathrm{M}$.

Hypoxia provides a means of increasing $\mathrm{Fe}$ absorption in mice without dietary manipulation, thus the contribution of mucosal regulation to control of Fe absorption can be studied without the complicating effect of changes in diet composition. No difference in chemically available forms of stomach $\mathrm{Fe}$ was detected in stomachs of hypoxic mice, which show enhanced Fe absorption (Simpson \& Peters, 1986). This suggests that an increased 
capability of the hypoxic mouse mucosa to take up available forms of dietary Fe can explain enhanced $\mathrm{Fe}$ absorption in these mice, and that no change in availability of dietary Fe occurs in the hypoxic mouse stomach.

The present findings provide identification and quantification of $\mathrm{Fe}$ species, present during dietary digestion and absorption, which can be related to Fe complexes used in model studies of Fe uptake by duodenal mucosa. These species include transient forms of Fe which are available for uptake by a proposed, non-esterified fatty acid-mediated, mucosal uptake mechanism, suggesting that this mechanism can operate in dietary $\mathrm{Fe}$ absorption.

The authors thank Dr J. F. Gibson, Department of Chemistry, Imperial College of Science and Technology, University of London for assistance with e.p.r. spectroscopy.

\section{REFERENCES}

Barton, J. C., Conrad, M. E. \& Parmley, R. T. (1983). Calcium inhibition of inorganic iron absorption in rats. Gastroenterology 84, 90-101.

Becker, G., Huebers, H.\& Rummel, W. (1979). Intestinal absorption of cobalt and iron: mode of interaction and subcellular distribution. Blut 38, 397-406.

Berner, L. A., Miller, D. D. \& Van Campen, D. (1986). Absorption of iron from ferric hydroxide polymers introduced into ligated rat duodenal segments. Journal of Nutrition 116, 259-264.

Conrad, M. E., Foy, A. L., Williams, H. L. \& Knospe, W. H. (1967). Effect of starvation and protein depletion on ferrokinetics and iron absorption. American Journal of Physiology 213, 557-565.

Cox, T. M. \& O'Donnell, M. W. (1981). Studies of the binding of iron by rabbit intestinal microvillus membranes. Biochemical Journal 194, 753-759.

Cox, T. M. \& Peters, T. J. (1979). The kinetics of iron uptake in vitro by human duodenal mucosa: studies in normal subjects. Journal of Physiology 289, 469-478.

Davis, P. S., Luke, C. G. \& Deller, D. J. (1967). Gastric iron binding protein in iron chelation by gastric juice. Nature 214, 1126.

Dorey, C., Dickson, D. P. E., St Pierre, T. G., Pollard, R. K., Gibson, J. F., Simpson, R. J. \& Peters, T. J. (1987). Iron species in iron ascorbate solutions at physiological pH. Biochemical Society Transactions $15,688$.

Eastham, E. J., Bell, J. I. \& Douglas, A. P. (1977). Iron-transport characteristics of vesicles of brush border and basolateral plasma membrane from the rat enterocyte. Biochemical Journal 164, $289-294$.

Forth, W. \& Rummel, W. (1973). Iron absorption. Physiology Reviews 53, $724-792$.

Forth, W. \& Schafer, S. G. (1987). Absorption of di- and trivalent iron. Experimental evidence. ArzneimForschung/Drug Research 37, 96-100.

Foy, A. L., Williams, H. L., Cortell, S. \& Conrad, M. E. (1967). A modified procedure for the determination of non-haem iron in tissue. Analytical Biochemistry 18, $559-563$.

Glover, J. \& Jacobs, A. (1971). Observations on iron in the jejunal lumen after a standard meal. Gut 12, 369--371.

Greenberger, N. J., Ruppert, R. D. \& Cuppage, E. E. (1967). Inhibition of intestinal iron transport induced by tetracycline. Gastroenterology 53, 590-599.

Helbock, H. L. \& Saltman, P. (1967). The transport of iron by rat intestine. Biochimica et Biophysica Acta 135, 979-990.

Hopping, J. M. \& Ruliffson, W. S. (1963). Effects of chelating agents on radioiron absorption and distribution in rats in vivo. American Journal of Physiology 205, 885-889.

Huebers, H., Huebers, E. \& Rummel, W. (1974). Dependence of increased iron absorption by iron-deficient rats on an elutable component of jejunal mucosa. Hoppe-Seyler's Zeitschrift für Physiologische Chemie 355, $1159-1161$.

Hungerford, D. M. \& Linder, M. C. (1983). Interactions of pH and ascorbate in intestinal iron absorption. Journal of Nutrition 113, 2615-2622.

Jacobs, A. \& Greenman, D. A. (1969). Availability of food iron. British Medical Journal i, 673-676.

James, A. H. \& Pickering, G. W. (1949). The role of gastric acidity in the pathogenesis of peptic ulcer. Clinical Science 8, 181-210.

Johnson, G., Jacobs, P. \& Purves, L. R. (1983). Iron binding proteins of iron-absorbing rat intestinal mucosa. Journal of Clinical Investigation 71, 1467-1476.

Kohler, G. D., Elvehjem, C. A. \& Hart, E. B. (1936). Modifications of the bipyridine method for available iron. Journal of Biological Chemistry 113, 4953.

Lock, S. \& Bender, A. E. (1980). Measurement of chemically-available iron in foods by incubation with human gastric juice in vitro. British Journal of Nutrition 43, 413-420. 
Manis, J. G. \& Schachter, D. (1964). Active transport of iron by intestine mucosal iron pools. American Journal of Physiology 207, 893-900.

Marx, J. J. M. \& Aisen, P. (1981). Iron uptake by rabbit intestinal mucosal membrane vesicles. Biochimica et Biophysica Acta 649, 297-304.

Muir, W. A., Hopfer, U. \& King, M. (1984). Iron transport across brush border membranes from normal and iron-deficient mouse upper small intestine. Journal of Biological Chemistry 259, 4896-4903.

Narasinga Rao, B. S. \& Prabhavathi, T. (1978). An in vitro method for predicting the bioavailability of iron from foods. American Journal of Clinical Nutrition 31, 169-175.

Pearson, W. N., Reich, M., Frank, H. \& Salamat, L. (1967). Effects of dietary iron level on gut iron levels and iron absorption in the rat. Journal of Nutrition 92, 53-65.

Peters, T. J., Raja, K. B., Simpson, R. J. \& Snape, S. (1988). Mechanisms and regulation of intestinal iron absorption. Annals of the New York Academy of Sciences 526, 141-147.

Raja, K. B., Simpson, R. J. \& Peters, T. J. (1987a). Comparison of ${ }^{59} \mathrm{Fe}^{3+}$ uptake in vitro and in vivo by mouse duodenum. Biochimica et Biophysica Acta 901, 52-60.

Raja, K. B., Simpson, R. J. \& Peters, T. J. (1987b). Effect of $\mathrm{Ca}^{2+}$ and $\mathrm{Mg}^{2+}$ on the uptake of $\mathrm{Fe}^{3+}$ by mouse intestinal mucosa. Biochimica et Biophysica Acta 923, 46-51.

Reddy, M. B., Chidambaram, M. V., Fonseca, J. \& Bates, G. W. (1986). Potential role of in vitro iron bioavailability studies in combatting iron deficiency: a study of the effects of phosvitin on iron mobilisation from pinto beans. Clinical Physiology and Biochemistry 4, 78-86.

Royston, J. P. (1983). Some techniques for assessing multivariate normality based on the Shapiro-Wilk $W$. Journal of the Royal Statistical Society 32C, 121-133.

Ruliffson, W. S. \& Hopping, J. M. (1963). Maturation, iron deficiency and ligands in enteric iron absorption. American Journal of Physiology 207, 893-900.

Sanford, R. (1960). Release of iron from conjugates in food. Nature 185, 533-534.

Savin, M. A. \& Cook, J. D. (1980). Mucosal iron transport by rat intestine. Blood 56, 1029-1035.

Shackleton, L. \& McCance, R. A. (1936). The ionizable iron in foods. Biochemical Journal 30, 582-591.

Simpson, R. J., Moore, R. \& Peters, T. J. (1988). Significance of non-esterified fatty acids in iron uptake by intestinal brush border membrane vesicles. Biochimica et Biophysica Acta 941, 39-47.

Simpson, R. J. \& Peters, T. J. (1984). Studies of $\mathrm{Fe}^{3+}$ transport across intestinal brush border membrane of the mouse. Biochimica et Biophysica Acta 772, 220-226.

Simpson, R. J. \& Peters, T. J. (1985). Fe ${ }^{2+}$ uptake by intestinal brush border membrane of the mouse. Biochimica et Biophysica Acta 814, 381-388.

Simpson, R. J. \& Peters, T. J. (1986). Mouse intestinal $\mathrm{Fe}^{3+}$ uptake kinetics in vivo. The significance of brushborder membrane vesicle transport in the mechanism of mucosal $\mathrm{Fe}^{3+}$ uptake. Biochimica et Biophysica Acta 856, $115-122$

Simpson, R. J. \& Peters, T. J. (1987). Transport of $\mathrm{Fe}^{2+}$ across lipid bilayers: possible role of free fatty acids. Biochimica et Biophysica Acta 898, 187-195.

Simpson, R. J., Raja, K. B. \& Peters, T. J. (1986). $\mathrm{Fe}^{2+}$ uptake by mouse intestinal mucosa in vivo and by isolated intestinal brush border membrane vesicles. Biochimica et Biophysica Acta 860, 229-235.

Stremmel, W., Lotz, G., Niederau, C., Teschke, R. \& Strohmeyer, G. (1987). Iron uptake by rat duodenal microvillus membrane vesicles: evidence for a carrier mediated process. European Journal of Clinical Investigation 17, 136-145.

Terato, K., Kiramatsu, Y. \& Yoshino, Y. (1973). Studies on iron absorption. II. Transport mechanism of low molecular weight iron chelate in rat intestine. Digestive Diseases 18, 129-134.

Thomson, A. B. R. \& Valberg, L. S. (1971). Kinetics of intestinal iron absorption in the rat: effect of cobalt. American Journal of Physiology 220, 1080-1085.

Webb, J., Multani, J. S., Saltman, P. \& Gray, H. B. (1973). Spectroscopic and magnetic studies of iron(iII) gastroferrin. Biochemistry 12, 265-267.

Wetherill, G. B. (1967). Elementary Statistical Methods. London: Methuen and Co. Ltd.

Wheby, M. S. \& Crosby, W. H. (1963). The gastrointestinal tract and iron absorption. Blood 22, 416-428.

Wynter, C. V. A. \& Williams, R. (1968). Iron-binding properties of gastric juice in idiopathic haemochromatosis. Lancet i, 534-537. 